Running title: Concussion

\title{
1 One-week test-retest reliability of nine binocular tests and saccades used
}

\section{2 in concussion}

4 Stephanie Long $\mathrm{MSc}^{1}$, Tibor Schuster $\mathrm{PhD}^{1}$, Russell Steele $\mathrm{PhD}^{2}$, Suzanne Leclerc MD PhD ${ }^{3}$,

$5 \quad$ lan Shrier MD $\mathrm{PhD}^{1,4}$

6 Author affiliations: ${ }^{1}$ Department of Family Medicine, McGill University; ${ }^{2}$ Department of

7 Mathematics and Statistics, McGill University; ${ }^{3}$ Institut National du Sport du Quebec, Montreal,

8 Canada; ${ }^{4}$ Centre for Clinical Epidemiology, Lady Davis Institute, Jewish General Hospital,

9 McGill University, Montreal, Canada

11 Corresponding Author:

12 Ian Shrier MD, PhD

13 Centre for Clinical Epidemiology,

14 Lady Davis Institute, Jewish General Hospital

153755 Cote Sainte-Catherine Road

16 Montreal, QC H3T 1E2

17 Canada

18 Email: ian.shrier@mcgill.ca 
medRxiv preprint doi: https://doi.org/10.1101/19011619; this version posted November 12, 2019. The copyright holder for this preprint (which was not certified by peer review) is the author/funder, who has granted medRxiv a license to display the preprint in perpetuity.

It is made available under a CC-BY-NC-ND 4.0 International license .

Running title: Concussion

\section{Abstract}

21 Background: Tests of binocular vision (BVTs) and ocular motility are used in concussion

22 assessment and management.

23 Purpose: To determine the one-week test-retest reliability of 9 binocular vision tests (BVTs) and

24 a test of saccades proposed for use in concussion management.

25 Study Design: Prospective test-retest.

26 Methods: We examined the one-week test-retest reliability of 9 BVTs in healthy participants: 3D

27 vision (gross stereoscopic acuity), phoria at $30 \mathrm{~cm}$ and $3 \mathrm{~m}$, ability of eyes to move/fixate in-sync

28 (positive and negative fusional vergence at $30 \mathrm{~cm}$ and $3 \mathrm{~m}$, near point of convergence and near

29 point of convergence - break [i.e. double vision]) and 1 ocular motor test, saccades.

Results: We tested 10 males and 10 females without concussion and a mean age of 25.5 (4.1)

31 years. The intraclass correlations suggest good reliability for phoria $3 \mathrm{~m}(0.88)$ and gross

32 stereoscopic acuity (0.86), and moderate reliability for phoria $30 \mathrm{~cm}(0.69)$, near point of

33 convergence (0.54), positive fusional vergence (0.54) and negative fusional vergence (0.66) at

$3430 \mathrm{~cm}$, and near point of convergence - break (0.64). There was poor reliability for saccades

35 (0.34), and both positive and negative fusional vergence (0.49 and 0.43 , respectively) at $3 \mathrm{~m}$.

36 Limits of agreement (LoA) were best for saccade ( $\pm 34 \%)$ and worst for phoria $30 \mathrm{~cm}( \pm 121 \%)$

37 and ranged from $\pm 58 \%$ to $\pm 70 \%$ for 7 of the 8 other tests. The LoA for phoria at $3 \mathrm{~m}$ were

38 uninformative because measurements for 18 of 20 participants were identical.

39 Conclusion: We found test-retest reliability of the BVTs and saccades ranging from poor to

40 good in healthy participants, with the majority being moderate.

41 Clinical Relevance: For these vision tests to be clinically useful, the effect of concussion must

42 have a moderate to large effect on the scores of most of the tests. 
medRxiv preprint doi: https://doi.org/10.1101/19011619; this version posted November 12, 2019. The copyright holder for this preprint (which was not certified by peer review) is the author/funder, who has granted medRxiv a license to display the preprint in perpetuity.

It is made available under a CC-BY-NC-ND 4.0 International license.

Running title: Concussion

43 Key Words:

44 concussion, vision, near point convergence, reliability

45

46 What is known about the subject:

47 - Concussions may affect some parts of visual function

48 - 1-week test-retest reliability for most visual tests is under-studied

49 What this study adds to existing knowledge:

50 - We provide intra-class coefficients and limits of agreement for 10 different visual function

$51 \quad$ tests commonly conducted by clinicians in patients with concussion.

52

53 
medRxiv preprint doi: https://doi.org/10.1101/19011619; this version posted November 12, 2019. The copyright holder for this preprint (which was not certified by peer review) is the author/funder, who has granted medRxiv a license to display the preprint in perpetuity.

It is made available under a CC-BY-NC-ND 4.0 International license .

Running title: Concussion

\section{Introduction}

55 Many brain-related disorders (e.g. concussion, ${ }^{29}$ Parkinson's Disease,${ }^{6}$ attention deficit

56 hyperactivity disorder, ${ }^{20}$ stroke ${ }^{44}$ ) have a visual component as part of their findings. ${ }^{24}$ For

57 example, posttraumatic vision impairments have been reported in $30 \%$ to $65 \%$ of patients with a

58 mild traumatic brain injury, ${ }^{11}$ and are found in nearly $30 \%$ of patients with a sport-related

59 concussion. ${ }^{25}$ Some symptoms associated with concussion are believed to be caused by

60 deficits in the visual system and include: headaches, sensitivity to light, diplopia, and blurred

61 vision. $^{12}$

62 Tests of binocular vision (BVTs) and ocular motility over the last 70 years ${ }^{9}$ include ${ }^{9,23,37}$ : gross

63 stereoscopic acuity, near point of convergence - break (i.e. double vision), phoria at $30 \mathrm{~cm}$ and

$643 \mathrm{~m}$, positive and negative fusional vergence at $30 \mathrm{~cm}$ and $3 \mathrm{~m}$, and saccadic eye movement

65 assessment. Recent studies have suggested that concussion may result in deficits of

66 convergence, binocular vision, and ocular motility. ${ }^{4,12,45}$ Convergence insufficiency is a disorder

67 of binocular vision diagnosed by abnormal near point of convergence, one of many BVTs that

68 assesses an individual's visual capacity.

69 Before we can conclude that visual function is abnormal in concussion, we must first understand

70 the test-retest reliability of vision tests in healthy control participants. Despite their frequent use,

71 limited studies have examined the reliability of these vision tests. When evaluating the one-

72 week test-retest reliability of the Randot Stereotest (test of gross stereoscopic acuity), 71-82\%

73 of adult and child participants with normal vision and with strabismus had perfect agreement

74 between two measurements: ${ }^{17,48}$ common psychometric properties such as intraclass

75 correlation coefficient (ICC) or limits of agreement (LoA) were not reported. An older study of

76 near point of convergence reported an ICC of 0.65 across six testing sessions in six healthy

77 adults, but failed to specify the number of examiners or the time interval between testing 
medRxiv preprint doi: https://doi.org/10.1101/19011619; this version posted November 12, 2019. The copyright holder for this preprint (which was not certified by peer review) is the author/funder, who has granted medRxiv a license to display the preprint in perpetuity.

It is made available under a CC-BY-NC-ND 4.0 International license .

Running title: Concussion

sessions. ${ }^{10}$ A study of near point of convergence - break in school-aged children reported excellent reliability (ICC $\geq 0.94) .{ }^{36}$ A more recent study of three consecutive measurements of near point of convergence - break without a rest interval between tests, found ICCs ranging

81 from 0.78-0.89 in young concussed athletes with convergence insufficiency and 0.92-0.97 in

82 concussed athletes with normal vision. ${ }^{31}$ When examining phoria with the prism alternate cover

83 test, one study reported $95 \%$ LoA of \pm 4.1 to \pm 7.3 prism diopters for distance and \pm 3.3 to \pm 8.3

84 prism diopters for near in young children with esotropia, but did not provide ICC. ${ }^{32}$ A one-week

85 test-retest reliability study assessing positive fusional vergence with a prism bar reported ICCs

86 ranging from $0.53-0.59 .{ }^{36}$ One to ten day test-retest reliability of the prism bar test had $95 \%$ LoA

$87 \pm 4.0$ for negative fusional vergence and \pm 13.9 for positive fusional vergence. ${ }^{5}$ Finally, the only

88 study we could find that measured reliability for saccades used a computerized prosaccade

89 task. The authors reported moderate two-month test-retest reliability $($ ICC $=0.59)$ in adult

90 participants with normal vision. ${ }^{16}$

91 The above studies provide some information regarding the reliability of these vision tests.

92 However, vision tests are used to follow patients over time, and one might expect additional

93 variability when patients are measured on different days due to fatigue, stress, and other

94 factors. Understanding the usual variability that is independent of changes in pathology or

95 recovery is essential for proper interpretation of trends in results over time. Therefore, the

96 objective of this study was to determine the one-week test-retest reliability of 9 BVTs and a test

97 of saccades in healthy adult participants. We evaluated versions of these visions tests that are

98 commonly used by clinicians as opposed to versions used in research studies in order to best

99 assess the utility of the tests in clinical practice. All tests in the present study were performed by

100 the same clinician on two testing dates. 
Running title: Concussion

\section{Methods}

\section{Study Design}

103 We examined a convenience sample of healthy colleagues, friends, and social connections in

104 Montreal, Canada on two separate occasions exactly seven days apart at approximately the 105 same time of day (e.g. morning vs. evening). One individual clinician trained in orthoptics

106 examined all participants individually. We arranged for 4-6 participants to be examined 107 sequentially in a two to three-hour block of time. We randomized the order in which participants 108 were examined using a random number generator within each block. To minimize the probability 109 of the clinician recalling the first scores at the second visit: (1) the clinician verbally reported the 110 results to a research assistant (recorded on paper) and was not informed of any scores until 111 data collection was completed, and (2) at the second visit, the same group of 4-6 participants 112 was examined over the same block of time but their examination order was changed compared 113 to the first visit. This study was approved by the Jewish General Hospital Institutional Review 114 Board.

\section{Participant Selection}

116 We included healthy adults 18 to 35 years. There were no participants with a history of 117 conditions that may affect BVTs (or treatment for such conditions) or saccades such as 118 strabismus (contraindication to BVTs), migraines, neurological disorders, or currently taking 119 muscle relaxants, selective serotonin-reuptake inhibitors, anxiolytics, stimulants, or any other 120 drug class for other psychological conditions that might affect test results. Although there were 121 three subjects with remote history of concussion, they had fully recovered and were not 122 experiencing concussion symptoms or related limitations at the time of our study. 
medRxiv preprint doi: https://doi.org/10.1101/19011619; this version posted November 12, 2019. The copyright holder for this preprint (which was not certified by peer review) is the author/funder, who has granted medRxiv a license to display the preprint in perpetuity.

It is made available under a CC-BY-NC-ND 4.0 International license .

Running title: Concussion

\section{Clinical procedures and measures}

124 We collected the following demographic information at the first visit: date of birth, sex, highest

125 level of education achieved, use of corrective lenses, occupation, and any relevant past medical

126 history (e.g. migraines, vision problems, use of medication, history of concussion).

127 Prior to conducting the vision tests, each participant first completed the symptom portion of the 128 validated sport concussion assessment tool (SCAT3) form. ${ }^{1,51}$ These results were used as a 129 sensitivity analysis to evaluate if changes in their physical states at the two testing sessions 130 might explain potential discrepancies.

\section{$131 \quad$ Vision Tests}

132 We examined 9 BVTs and a test of saccades. For gross stereoscopic acuity, near point of 133 convergence, near point of convergence - break and phoria, a lower score represents better

134 vision function. For positive and negative fusional vergence, and saccades, a higher score 135 represents better vision function. Brief descriptions of each are provided below and more details 136 are available in the Appendix.

137 For gross stereoscopic acuity, we used the Randot Stereotest (Stereo Optical Co., Inc., 138 Chicago, IL) according to manufacturer's instructions. ${ }^{43}$ For all tests using a target, the tip of a 139 ballpoint pen was used as the near target, and a $6 \mathrm{~cm}^{2}$ square card mounted on a wall was used 140 as the far target. For near point of convergence and near point of convergence - break, we 141 followed procedures by Maples et al. ${ }^{27}$ The near point of convergence score was the distance $142(\mathrm{~cm})$ between the bridge of the nose and the target at the closest point at which the individual 143 could maintain balanced oculomotor synergy between both eyes, which is identified as when 144 one eye diverges outwards. ${ }^{9}$ The near point of convergence - break score was the distance 145 between the bridge of the nose and the point at which diplopia occurred. ${ }^{7,23}$ We measured 146 phoria at $30 \mathrm{~cm}$ and $3 \mathrm{~m}$ using the prism alternate cover test with procedures described by the 
medRxiv preprint doi: https://doi.org/10.1101/19011619; this version posted November 12, 2019. The copyright holder for this preprint (which was not certified by peer review) is the author/funder, who has granted medRxiv a license to display the preprint in perpetuity.

It is made available under a CC-BY-NC-ND 4.0 International license .

Running title: Concussion

147 Pediatric Eye Disease Investigator Group. ${ }^{32}$ For positive and negative fusional vergence at

$14830 \mathrm{~cm}$ and $3 \mathrm{~m}$, we used a horizontal prism bar (base-out for positive fusional vergence, base-in

149 for negative fusional vergence). ${ }^{19}$ To evaluate saccades, we used the specific testing

150 procedures of our clinician. In his test of saccades, participants assumed a tandem stance and

151 attempted to move only their eyes when lights appeared and disappeared (using a gap protocol

152 in which the first light disappeared before the second appeared) on the screen. The clinician

153 evaluated their performance qualitatively along three measures: quality (bad, medium, good),

154 synchronization (bad, medium, good), and saccadic correction (many, few, none).

\section{Statistical Analysis}

156 Reliability Estimates

157 We evaluated test-retest reliability using statistical measures for consistency and accuracy i.e.

158 the intra class correlation coefficient (ICC) $)^{42}$ and $95 \%$ limits of agreement (LoA). ${ }^{8}$ We considered 159 an ICC of $\leq 0.5$ as poor, $0.51-0.74$ as moderate, $0.75-0.89$ as good, and $\geq 0.90$ as excellent

160 reliability. ${ }^{26}$ When multiple participant scores were the same, we used the jitter function in the $R$

161 software ${ }^{34}$ to slightly modify the scores when plotting the results so they would appear distinct

162 from each other.

163 The LoA were calculated as recommended in the units of the scale measured. ${ }^{8}$ To compare LoA 164 across tests, we also standardized the scores and reported them as percentage difference [(T1$165 \mathrm{~T} 2) /$ mean(T1\&T2)*100]. The LoA results were summarized graphically with Bland-Altman plots. ${ }^{8}$

166 We used the raw scale measures commonly known to clinicians for the y-axis, and report the

167 standardized version in parentheses to provide an overview of all tests.

168 Due to the limited sample size and to avoid being overly conservative in our evaluation, we

169 followed the practical solution for addressing multiple testing proposed by Saville. ${ }^{38}$ Formal 
medRxiv preprint doi: https://doi.org/10.1101/19011619; this version posted November 12, 2019. The copyright holder for this preprint (which was not certified by peer review) is the author/funder, who has granted medRxiv a license to display the preprint in perpetuity.

It is made available under a CC-BY-NC-ND 4.0 International license .

Running title: Concussion

170 multiplicity correction of confidence levels was not performed but we thoroughly report all

171 statistical assessments enabling an informal type / error assessment by the reader.

\section{Effect of Physical State}

173 As a sensitivity analysis, we wanted to explore if a participant's change in physical state could

174 have been associated with their vision test scores. We, therefore, compared the change in

175 BVTs and saccade scores against the change in SCAT3 symptom scores using the Pearson's

176 correlation coefficient. Although we report $p$-values for these comparisons, we caution that

177 these are minimum values as we did not correct for multiple testing.

178 All statistical analyses were performed on R software 3.4.3., ${ }^{34}$ plots were created using the 179 ggplot2 package. ${ }^{50}$

\section{A priori sample size calculation}

181 Sample size calculations were done prior to the study. We used a precision-based method for 182 sample size calculations based on the ICC. Since the expected estimate for ICCs is zero, our 183 sample size calculation relied on specifying the maximum acceptable width of the confidence 184 interval for the measure of agreement. We considered the lower bound of clinical acceptability 185 to be an ICC of $0.5,{ }^{49}$ and expected the true ICC for repeated assessment of the different vision 186 test scores to be at least 0.75 . Therefore, we believed that our estimate imprecision ( $95 \%$ 187 confidence interval width / 2) should not exceed 0.25 . With 20 participants, under the postulated 188 assumptions, the precision of the ICC estimate was anticipated to be $\pm 0.20 .^{49}$

\section{Results}

190 Of 47 potential participants identified, 26 had scheduling conflicts, one was not able to attend

191 the second visit and was excluded from the analysis, leaving 20 participants for the final 192 analysis. 
medRxiv preprint doi: https://doi.org/10.1101/19011619; this version posted November 12, 2019. The copyright holder for this preprint (which was not certified by peer review) is the author/funder, who has granted medRxiv a license to display the preprint in perpetuity.

It is made available under a CC-BY-NC-ND 4.0 International license.

Running title: Concussion

193 Demographic data for the sample analyzed is included in Table 1. Our sample included 50\%

194 females with an average age of 25.5 years $(S D=4.1$, range=18-35), almost all university

195 educated, with 55\% wearing corrective lenses with an up-to-date prescription. None of the

196 participants had any history of vision symptoms or a history of past binocular vision therapy.

197 There were six participants who had previously sustained one or two concussions, which

198 occurred 2 to 15 years prior to our study; none of these individuals reported any residual

199 concussion symptoms at the time of our study. Additionally, the three participants who had

200 reported taking selective serotonin reuptake inhibitors or anxiolytics had not received the

201 medication for at least five years as they no longer suffered from the condition. 
medRxiv preprint doi: https://doi.org/10.1101/19011619; this version posted November 12, 2019. The copyright holder for this preprint (which was not certified by peer review) is the author/funder, who has granted medRxiv a license to display the preprint in perpetuity.

It is made available under a CC-BY-NC-ND 4.0 International license .

Running title: Concussion

\section{Table 1: Demographic and clinical characteristics of participants}

\begin{tabular}{|c|c|}
\hline Characteristic & No. (\%) \\
\hline No. of participants (1 lost to follow-up) & 21 \\
\hline Male & $10(50)$ \\
\hline Female & $10(50)$ \\
\hline \multicolumn{2}{|l|}{ Highest level of education attained: } \\
\hline High school & $1(5)$ \\
\hline University & $19(95)$ \\
\hline \multicolumn{2}{|l|}{ Current status: } \\
\hline Enrolled in school & $10(50)$ \\
\hline Working & $5(25)$ \\
\hline School \& working & $5(25)$ \\
\hline \multicolumn{2}{|l|}{ Vision correction: } \\
\hline Corrective lenses & $11(55)$ \\
\hline No correction & $9(45)$ \\
\hline \multicolumn{2}{|l|}{ No. concussion previously sustained: } \\
\hline 0 & $14(70)$ \\
\hline 1 & $3(15)$ \\
\hline 2 & $3(15)$ \\
\hline \multicolumn{2}{|l|}{ Past medical history: } \\
\hline Received medication for depression & $2(10)$ \\
\hline Received medication for anxiety & $1(5)$ \\
\hline Received medication for ADHD & $0(0)$ \\
\hline
\end{tabular}


Running title: Concussion

205 Baseline (i.e. Visit 1) scores for all tests quantitatively scored can be found in Table 2. The

206 mean scores of these tests are within range of normative scores reported in the literature (see

207 Appendix for more details).

\begin{tabular}{|l|r|}
\hline \multicolumn{2}{|c|}{ Table 2: Baseline scores for quantitatively scored vision tests } \\
\hline Test (normal range) & Mean (SD) \\
\hline Gross stereoscopic acuity (20-100 arc seconds) & $42.5(20.2)$ \\
\hline Near point of convergence $(3-7 \mathrm{~cm})$ & $4.6(1.1)$ \\
\hline Near point of convergence - break (1-8 cm) & $5.2(1.5)$ \\
\hline Phoria - 3m (44-90 prism diopters) & $0.3(1.0)$ \\
\hline Phoria - 30cm (1-45 prism diopters) & $19.5(11.2)$ \\
\hline Positive fusional vergence $-3 \mathrm{~m}(6-45$ prism diopters) & $16.8(8.5)$ \\
\hline Positive fusional vergence $-30 \mathrm{~cm}(10-40$ prism diopters) & $25.3(9.5)$ \\
\hline Negative fusional vergence $-3 \mathrm{~m}(2-8$ prism diopters) & $5.4(1.8)$ \\
\hline Negative fusional vergence - 30cm (4-30 prism diopters) & $18.5(6.7)$ \\
\hline
\end{tabular}

209 Two BVTs achieved good reliability. For phoria 3m (ICC=0.88), 18 out of 20 pairs of

210 measurements were identical at test and retest, with one participant scoring 0 and 1 prism

211 diopters, and the other scoring 0 and 2 prism diopters. Due to this highly skewed score

212 distribution, the $95 \%$ LoA are relatively uninformative (data not shown). The ICC for gross

213 stereoscopic acuity was 0.86 (Figure 1). For this test, 5 out of 20 pairs of measurements were

214 identical, with the remaining pairs differing by 5 to 40 arc seconds; the $95 \%$ LoA was \pm 27.6 arc

215 seconds. 
Running title: Concussion

Gross Stereoscopic Acuity (arc seconds)
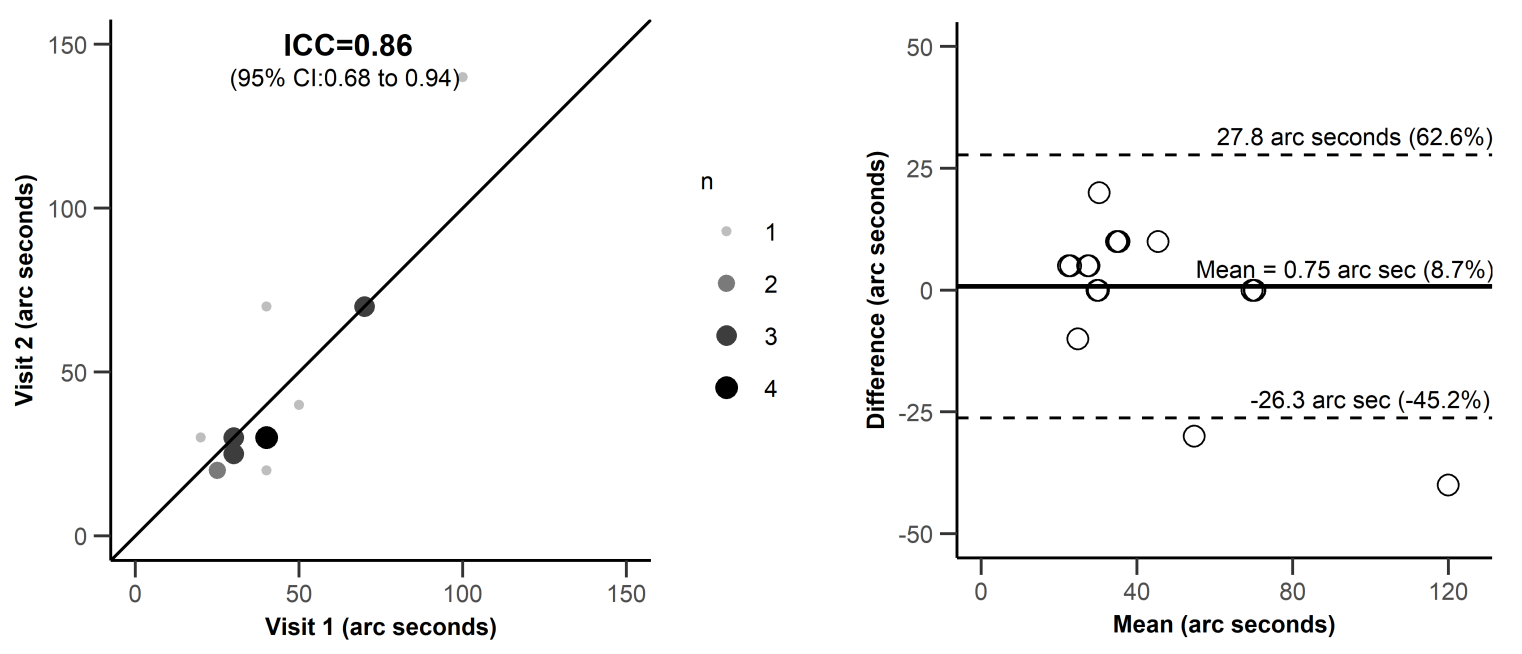

Figure 1: The left graph is a scatter plot for the test results at the first visit (x-axis) and retest results at the second visit (y-values) for gross stereoscopic acuity (GSA). The intra-class coefficient and its $95 \%$ confidence intervals are illustrated on the graph. The size of the gray dots (and $\mathrm{n}$ in the legend) represents the number of subjects with the values shown on the graph. The line of equality indicates where all points would fall if reliability was perfect. The right graph represents the BlandAltman plot with the mean of the test-retest values on the x-axis and the difference between the test-retest results on the y-axis. The solid line represents the bias and the dotted lines represent the $95 \%$ limits of agreement (LoA). The $y$-axis scale represents the raw units of the test because these are the most relevant to the clinician treating the patient. Because we conducted many tests and readers may be interested in comparing the LoA across tests, we also report LoA as percent difference (T1-T2/mean of T1\&T2) in parentheses. 
medRxiv preprint doi: https://doi.org/10.1101/19011619; this version posted November 12, 2019. The copyright holder for this preprint (which was not certified by peer review) is the author/funder, who has granted medRxiv a license to display the preprint in perpetuity. It is made available under a CC-BY-NC-ND 4.0 International license.

Running title: Concussion

232 We found moderate reliability for near point of convergence, near point of convergence - break,

233 phoria $30 \mathrm{~cm}$, and for positive and negative fusional vergence at $30 \mathrm{~cm}$ (Figures 2 and 3), with

234 ICCs ranging between 0.54 to 0.69 . For these BVTs, the $95 \%$ LoA was $\pm 2.5 \mathrm{~cm}$ for near point of

235 convergence, $\pm 2.5 \mathrm{~cm}$ for near point of convergence - break, \pm 16.3 prism diopters for phoria

$23630 \mathrm{~cm}$, and \pm 17.3 prism diopters and \pm 10.4 prism diopters respectively for positive and negative

237 fusional vergence at $30 \mathrm{~cm}$. 
Running title: Concussion

\section{Nearpoint of Convergence $(\mathrm{cm})$}
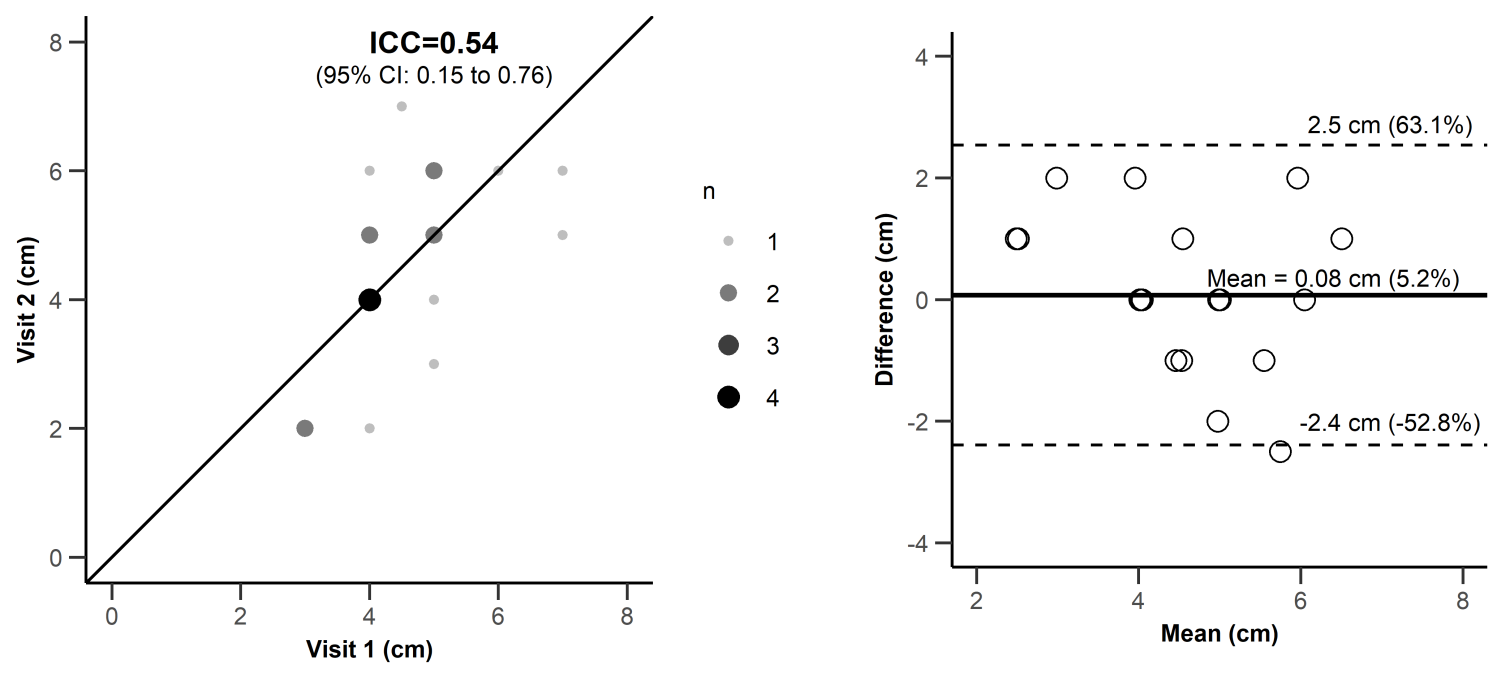

Nearpoint of Convergence-break (cm)
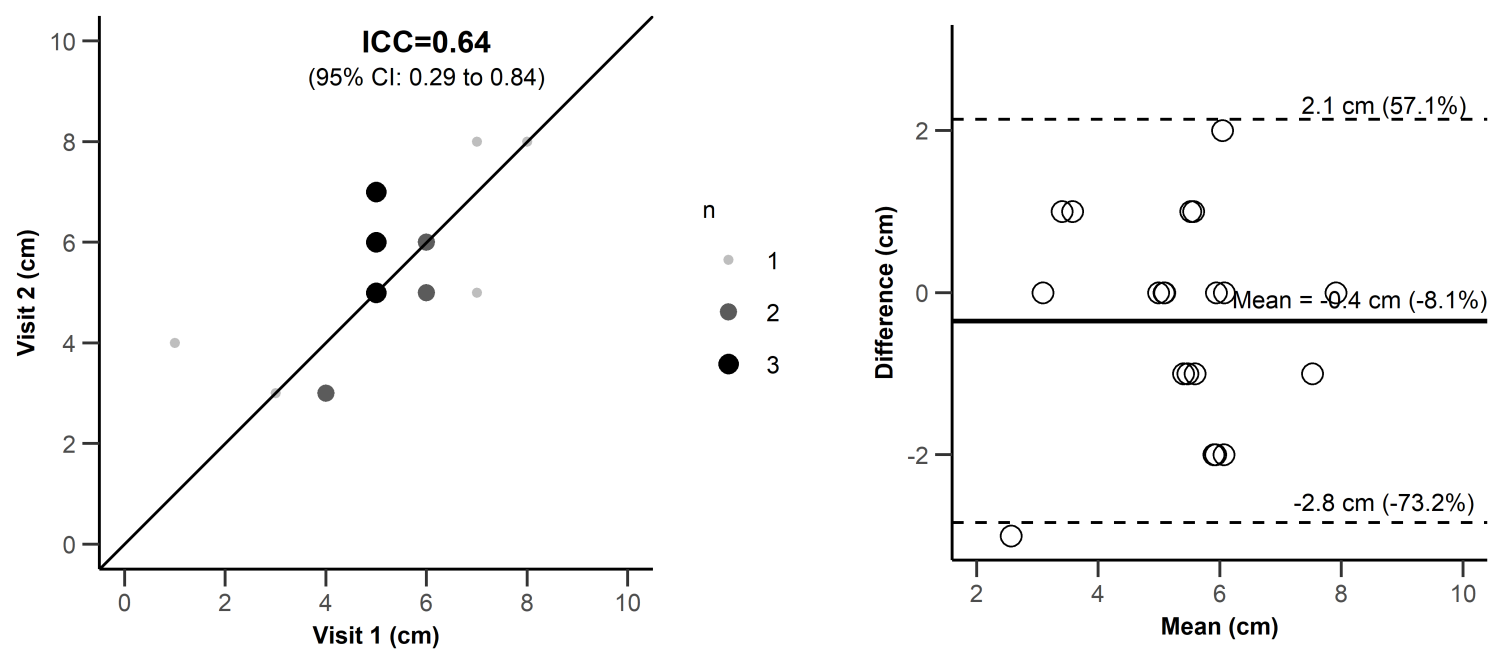

Figure 2: Scatter plots with intra-class coefficient results for the test-retest results 
medRxiv preprint doi: https://doi.org/10.1101/19011619; this version posted November 12, 2019. The copyright holder for this preprint (which was not certified by peer review) is the author/funder, who has granted medRxiv a license to display the preprint in perpetuity.

It is made available under a CC-BY-NC-ND 4.0 International license .

Running title: Concussion

Phoria $30 \mathrm{~cm}$ (prism diopters, PD)
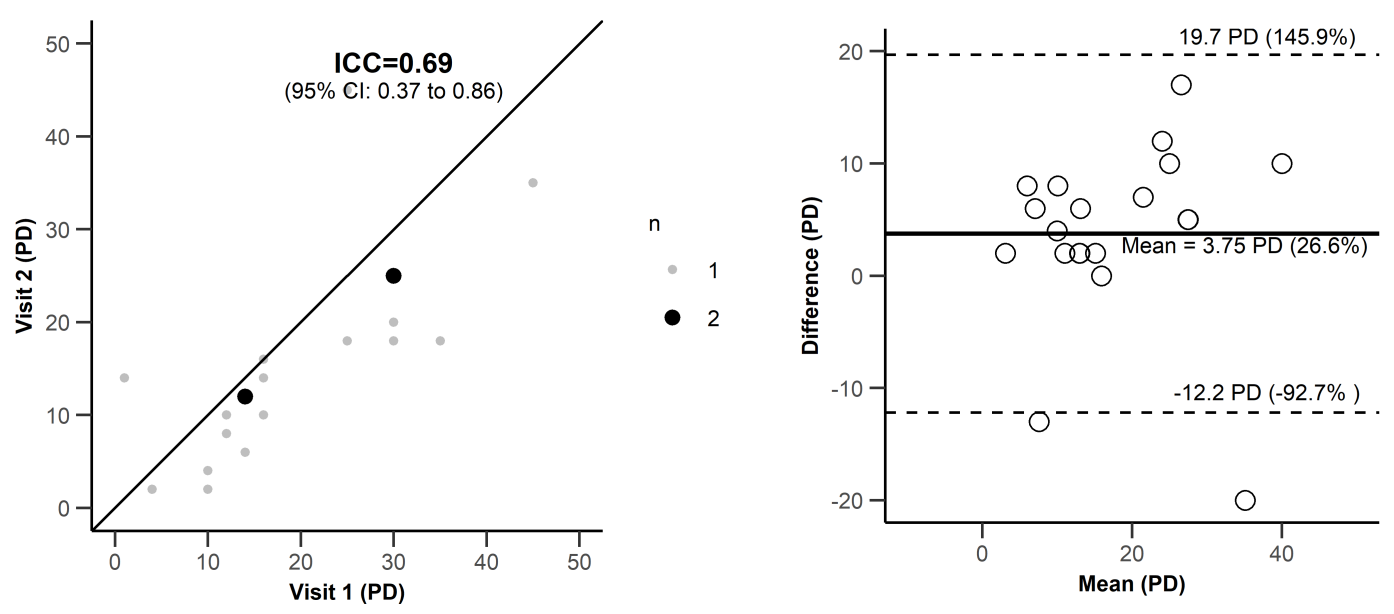

Negative Fusional Vergence $30 \mathrm{~cm}$ (prism diopters, PD)
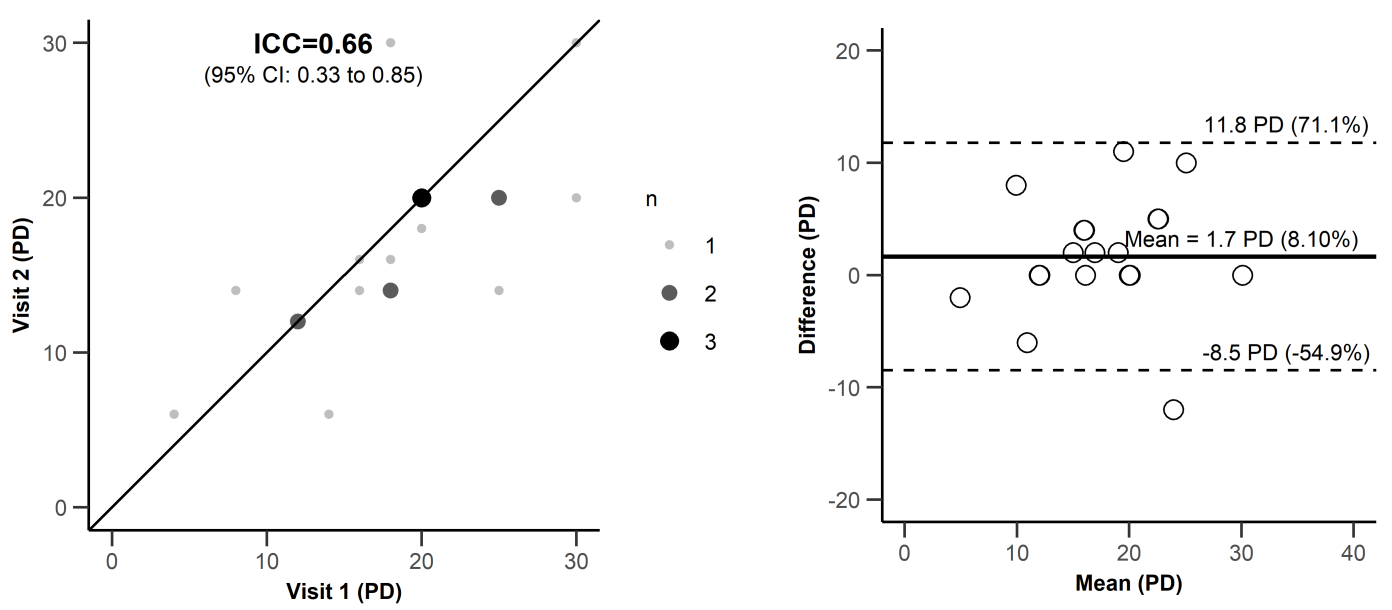

Positive Fusional Vergence $30 \mathrm{~cm}$ (prism diopters, PD)
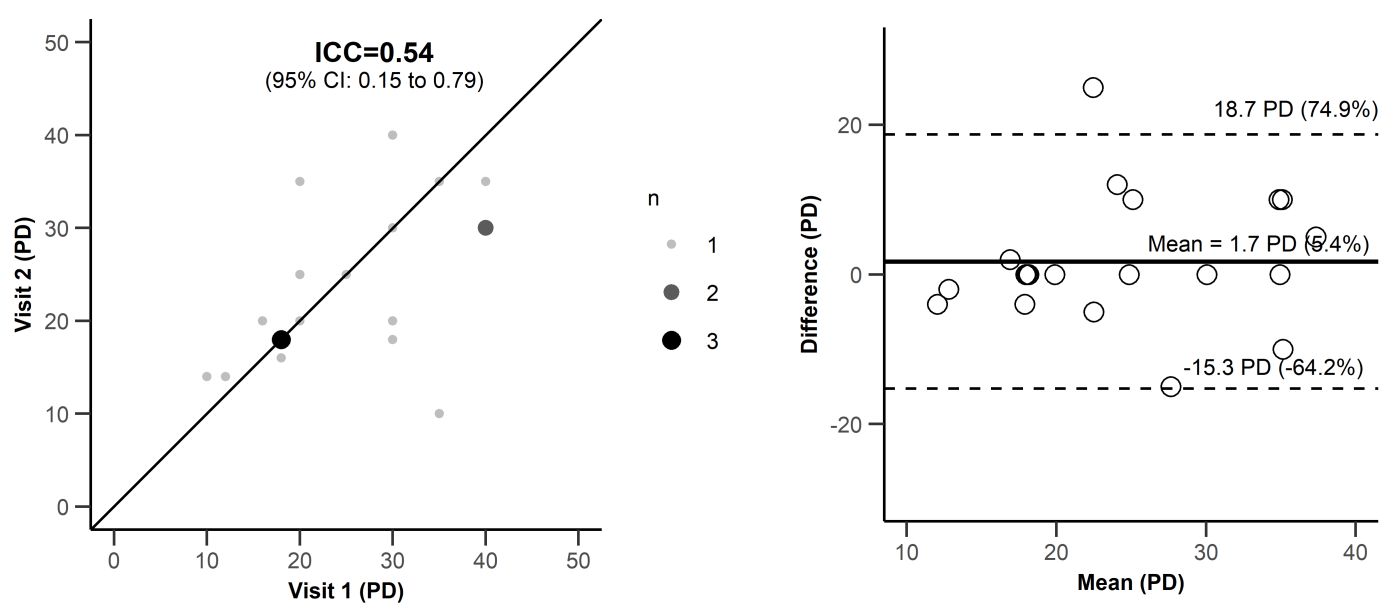
medRxiv preprint doi: https://doi.org/10.1101/19011619; this version posted November 12, 2019. The copyright holder for this preprint (which was not certified by peer review) is the author/funder, who has granted medRxiv a license to display the preprint in perpetuity. It is made available under a CC-BY-NC-ND 4.0 International license.

Running title: Concussion

Figure 3: Scatter plots with intra-class coefficient results for the test-retest results (left) and limits of agreement (LoA, right) for one-week test-retest reliability for the remaining $3 / 5$ binocular vision tests with moderate reliability. Legends are identical to Figure 1.

251 The three tests with poor reliability were positive and negative fusional vergence at $3 \mathrm{~m}$, and 252 saccades (Figure 4). 
medRxiv preprint doi: https://doi.org/10.1101/19011619; this version posted November 12, 2019. The copyright holder for this preprint (which

It is made available under a CC-BY-NC-ND 4.0 International license.

Running title: Concussion

Negative Fusional Vergence 3m (prism diopters, PD)
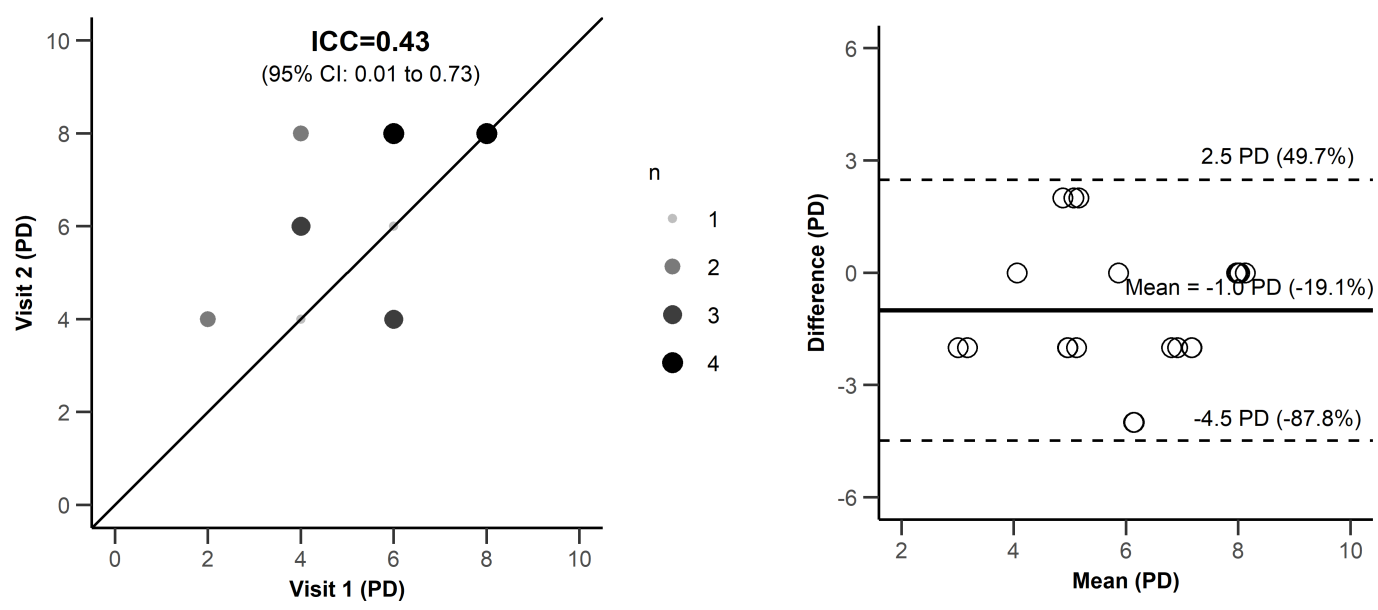

Positive Fusional Vergence 3m (prism diopters, PD)
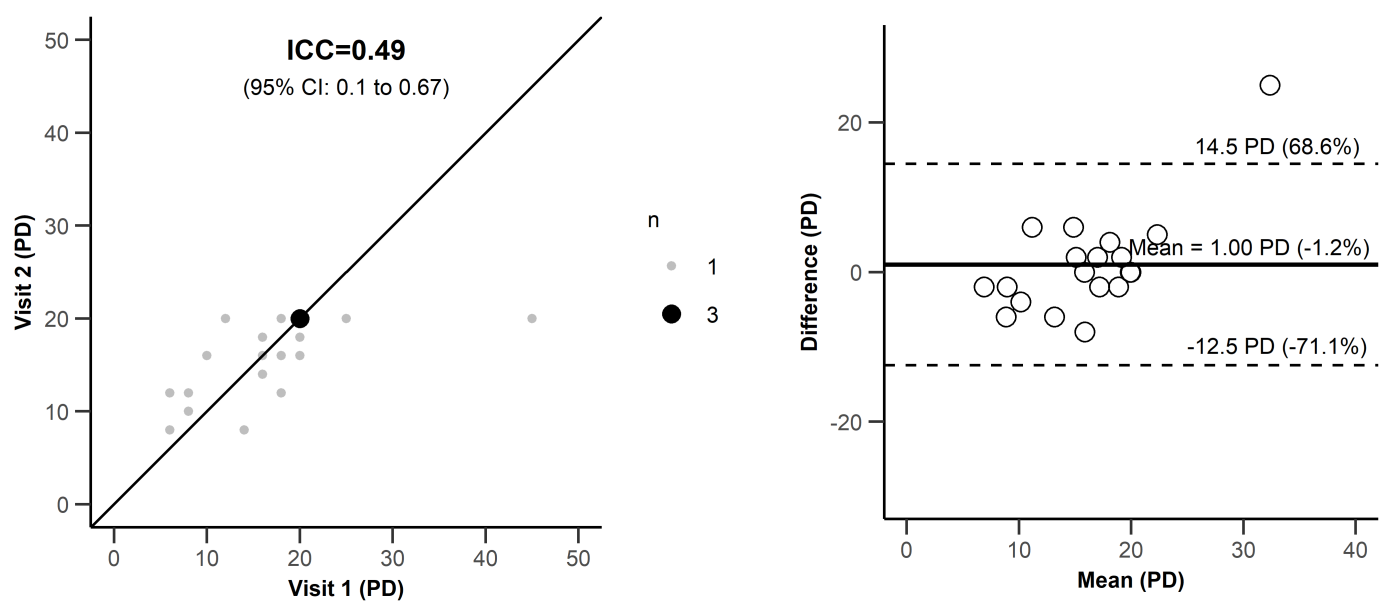

Saccades (\%)
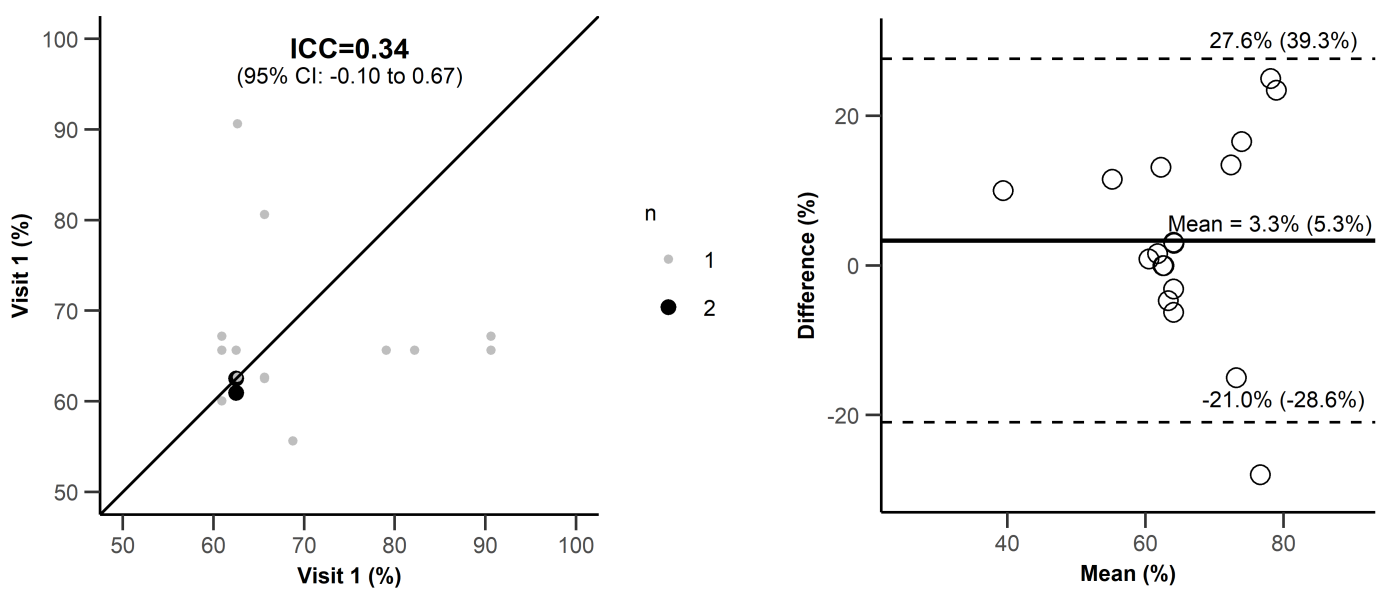
medRxiv preprint doi: https://doi.org/10.1101/19011619; this version posted November 12, 2019. The copyright holder for this preprint (which was not certified by peer review) is the author/funder, who has granted medRxiv a license to display the preprint in perpetuity.

It is made available under a CC-BY-NC-ND 4.0 International license .

Running title: Concussion

Figure 4: Scatter plots with intra-class coefficient results for the test-retest results (left) and limits of agreement (LoA, right) for one-week test-retest reliability for

\section{Effect of Changes in Physical State}

260 In our sensitivity analysis, a participant's physical state (as measured by the SCAT3 symptom

261 score) was not relevantly associated with their BVT scores across testing sessions. Pearson's

262 correlations between changes in vision test scores and changes in symptom scores ranged

263 from -0.006 to 0.31 for all vision tests ( $p$-values ranged from 0.19 to 0.98 ).

\section{Discussion}

265 Our results suggest that only 2 out of 10 vision tests demonstrated good reliability, and 5

266 additional tests had moderate reliability. There was poor reliability for saccades and both

267 positive and negative fusional vergence at $3 \mathrm{~m}$. The 95\% LoA suggests that even with good or

268 moderate reliability, one can expect that scores for an individual with repeated measures may

269 vary by $50-70 \%$ of the mean score across all measures even if there is no change in visual

270 function. These results highlight the need for more accurate, quantifiable, and repeatable tests

271 since one might expect even more variability in a patient population compared to the healthy

272 population that we studied. Further studies are necessary to determine if changes to visual

273 function with concussion or other neurological injury (the resultant signal) are large enough to

274 be noticed given the amount of inherent noise in the tests.

275 We used the Randot Stereotest to assess gross stereoscopic acuity. Our ICC of 0.86 and $95 \%$

276 LoA of \pm 27.6 arc seconds support previous findings of good reliability in adults in the one-week 
medRxiv preprint doi: https://doi.org/10.1101/19011619; this version posted November 12, 2019. The copyright holder for this preprint (which was not certified by peer review) is the author/funder, who has granted medRxiv a license to display the preprint in perpetuity. It is made available under a CC-BY-NC-ND 4.0 International license .

Running title: Concussion

277 time frame. The 95\% LoA were previously reported as $\pm 0.57 \log$ arc seconds (our results are $278 \pm 0.58$ log arc seconds using the same method of calculation) based on 36 patients between 7 to 27976 years of age; time between testing intervals ranged from 10 to 364 days using a different 280 examiner at each time point. ${ }^{2}$ Another study reported that $82.0 \%$ of their participants had 281 identical results at test and retest taken same day in 111 adult and children with normal vision, 282 but normal psychometric properties such as ICC or LoA were not reported. ${ }^{48} \mathrm{~A}$ study examining 283 the one-week test-retest reliability of gross stereoscopic acuity using the related Titmus fly test 284 in 90 children reported perfect reliability $(I C C=1.0)^{28}$. The Random dot "E" stereotest reported 285 only interrater agreement $\left(K_{w}=0.33-0.44\right)$ in 1257 children, but not test-retest reliability. ${ }^{46}$

286 In the literature, there is no clear distinction between measures of near point of convergence 287 and near point of convergence - break. Further, near point of convergence is sometimes 288 referred to as a measurement of gross convergence with fusional convergence ${ }^{22}$ and other 289 times as gross convergence with proximal convergence. ${ }^{21,22,47}$ The inconsistent use of these 290 terms complicates comparisons across studies when the measurement procedure is not 291 reported. The Convergence Insufficiency Treatment Trial Study ${ }^{13}$ considered near point of 292 convergence - break as the point "[w]hen diploplia was reported," which is consistent with our 293 definition. ${ }^{7,23}$ We defined near point of convergence as the closest point at which one eye 294 diverges outwards. ${ }^{9,23,37}$ Across the literature, near point of convergence and near point of 295 convergence - break are sometimes used interchangeably. For instance, near point of 296 convergence has been defined as the point "when the target blurs, jumps or becomes double,"37 297 "when [the participant] saw 2 distinct images," ${ }^{31}$ and "when the patient reported diplopia".

298 We found moderate reliability for both near point of convergence and near point of convergence 299 - break, whereas others have reported good to excellent reliability. ${ }^{31,36}$ In our measurement 300 procedure, participants fixated on a target that the clinician moved towards their eyes in free 301 space as used by some clinicians and researchers in the concussion field. ${ }^{29}$ Others used an 
medRxiv preprint doi: https://doi.org/10.1101/19011619; this version posted November 12, 2019. The copyright holder for this preprint (which was not certified by peer review) is the author/funder, who has granted medRxiv a license to display the preprint in perpetuity.

It is made available under a CC-BY-NC-ND 4.0 International license .

Running title: Concussion

accommodative target, such as the Royal Air Force (RAF) rule, ${ }^{7,37}$ or Astron International (ACR/21) Accommodative Rule. ${ }^{13,22,36,40}$ The RAF rule had good (ICC=0.84) test-retest reliability

304 for near point of convergence in 3 subjects with idiopathic neck pain and 7 healthy subjects, but

305 the test interval was only specified as less than one-week. ${ }^{18}$ The Astron International

306 Accommodative Rule had excellent one-week test-retest reliability (ICC=0.94-0.98) in 20

307 healthy children for near point of convergence - break. ${ }^{36}$ Although tests using these

308 accommodative targets may have increased reliability compared to the methods used in this

309 study, one would generally like to minimize the accommodative load in patients with concussion

310 because it may increase symptoms. Some of the variability in our results is likely explained by

311 accommodation variability in our participants. We found no studies directly comparing the

312 reliability of the different procedures. Sheiman et al ${ }^{39}$ and Rouse et al ${ }^{36}$ provide a more

313 complete discussion of the advantages and disadvantages of the different methods used to

314 assess near point of convergence.

315 Measurements of phoria using the prism alternate cover test had good reliability for distance

$316(I C C=0.88)$ and moderate reliability for near $(I C C=0.69)$. These results are consistent with other

317 studies which measured adult and child participants with strabismus or esotropia, ${ }^{14,32}$ even

318 though none of our participants had these conditions. Despite the similarity in findings, our

319 analysis methods differed slightly. For instance, because different prism increments are used to

320 measure smaller (2-20 prism diopters) or larger (>20 prism diopters) angles, other authors

321 analyzed and reported these strata separately. ${ }^{14,32}$ Unlike other authors, we evaluated all angles

322 of deviation together.

323 For both positive and negative fusional vergence, we reported moderate reliability (ICC=0.54,

3240.66 respectively) for near fixation and poor reliability (ICC $=0.49,0.43$ respectively) for distance

325 fixation. These results are contrary to studies reporting lower within-subject variability at near 326 fixation, ${ }^{33}$ or no differences due to distance. ${ }^{5}$ Further, we found that negative fusional vergence 
medRxiv preprint doi: https://doi.org/10.1101/19011619; this version posted November 12, 2019. The copyright holder for this preprint (which was not certified by peer review) is the author/funder, who has granted medRxiv a license to display the preprint in perpetuity.

It is made available under a CC-BY-NC-ND 4.0 International license .

Running title: Concussion

327 had slightly higher reliability than positive fusional vergence at near, but were less reliable at 328 distance. However, standard clinical practice and evidence suggests the opposite; negative

329 fusional vergence is considered to have less reliability than positive fusional vergence. ${ }^{3,35}$ It is

330 possible that the order in which fusional vergences are taken may influence their scores. We

331 measured fusional vergences grouped by distance: (1) negative fusional vergence far, (2)

332 positive fusional vergence far, (3) negative fusional vergence near, and (4) positive fusional

333 vergence near. However, the reliability was poor for both tests at distance suggesting the order

334 of test administration would not explain the discrepancy between our results and the literature. It

335 remains possible that our results are different than others because of slight differences in our

336 methods that are not apparent in the description of the tests (see Appendix for full description of

337 our methods).

338 The test of saccades had the lowest ICC and poorest reliability of all the vision tests. We used

339 the clinical procedures our clinician uses in his daily practice with his patients. Participants

340 assumed a tandem stance and attempted to follow appearing and disappearing lights on a

341 screen under a gap paradigm with only their eyes, trying to keep their head still. The clinician

342 stood beside the screen in front of the participant to observe their eye movements. In some

343 published saccade test protocols, the participant's head is held still with a chin rest and a

344 forehead support to ensure that only the eyes are tracking the movements. ${ }^{16,30}$ In the NSUCO

345 oculomotor test, the head is not held still. ${ }^{41}$ However, unlike other tests of saccades, our

346 clinician had patients take a tandem stance which adds an additional vestibular challenge. The

347 added challenge may influence their performance on the task and introduce more noise. Finally,

348 the evaluation of the saccades was qualitative, dependent solely on the judgment of the clinician

349 with no objective measure. 
medRxiv preprint doi: https://doi.org/10.1101/19011619; this version posted November 12, 2019. The copyright holder for this preprint (which was not certified by peer review) is the author/funder, who has granted medRxiv a license to display the preprint in perpetuity. It is made available under a CC-BY-NC-ND 4.0 International license .

Running title: Concussion

\section{Strengths and Limitations}

351 We selected a seven-day interval between testing times to evaluate the test-retest reliability of

352 the vision tests. This allowed for normal variation over time due to sleep, stress, and other

353 factors in order to provide an ICC that is applicable to following patients over time. In addition, it

354 avoids any lingering symptoms following a test that might lead to an underestimated ICC. The

355 seven-day interval also increased the likelihood the clinician remained blinded to the previous

356 results and facilitated participant recruitment because we could select a day and time when

357 participants were generally available. Some studies previously evaluated interrater

358 reliability. ${ }^{14,17,32,36}$ Although this has merit when one is interested in tests being evaluated by

359 more than one clinician as what might occur in group practice or a research study, interrater

360 reliability is less important when patients are followed by a single clinician over time. Our

361 objective was to define the expected "noise" when a single clinician follows a single patient over

362 time, as would occur in our target condition (i.e. concussions), so that clinicians can

363 appropriately interpret changes in the vision test scores. We provided results based on different

364 perspectives of reliability. The ICC is a measure of variability due to genuine differences in the

365 participant or due to measurement error. For instance, the ICC was 0.88 for phoria $3 \mathrm{~m}$,

366 indicating that $88 \%$ of the variability in the measurements was due to differences between

367 participants, and $12 \%$ was due to noise within the measurement of a participant. In addition, the

$36895 \%$ LoA provides the magnitude of the noise that can be expected with repeated measures.

369 Differences between tests at baseline and after diagnosis of a condition (e.g. concussion) likely

370 represent a true signal of a change in vision tests within the patient if these differences are

371 larger than the noise (i.e. LoA) found in our study.

372 Our study also had limitations with respect to participant population and testing measures. We

373 had a relatively small homogeneous sample size of 20 participants who were recruited via

374 convenience sampling in a university setting. However, our participants did include an equal 
medRxiv preprint doi: https://doi.org/10.1101/19011619; this version posted November 12, 2019. The copyright holder for this preprint (which was not certified by peer review) is the author/funder, who has granted medRxiv a license to display the preprint in perpetuity.

It is made available under a CC-BY-NC-ND 4.0 International license .

Running title: Concussion

375 number of males and females, over half wore corrective lenses, and the age range was 18 to 35

376 years. Our study population was thus relatively representative of our target population of young

377 athletes who may sustain concussions. The approaches used by our clinician were standard to

378 his clinical practice and were used on both of the testing days for all participants. However, the

379 methods he used to assess vision function sometimes differed from testing procedures reported

380 in the literature. For instance, a testing distance of $30 \mathrm{~cm}$ was used instead of the standard 40

$381 \mathrm{~cm}$ distance for near testing of positive and negative fusional vergence. ${ }^{5}$ The near testing

382 distance of $30 \mathrm{~cm}$ was also used for phoria, which is similar to the distance commonly used in

383 the literature, $1 / 3 \mathrm{~m} \cdot{ }^{14,32}$ However, we are not aware of any studies comparing the effect of

384 distance on reliability. Our clinician did not attempt to separate out accommodative testing from

385 convergence (i.e. near point of convergence and near point of convergence - break, also known

386 as relative convergence) although this may be possible. ${ }^{15}$ Therefore, our measure of

387 convergence could have been affected by accommodative issues. The saccadic eye movement

388 test of our clinician also differs from commonly used tests in clinical practice and the scoring of

389 this test was qualitative and subjective, which could lead to increased variability and

390 inconsistency in scoring. Developing more quantifiable and reliable testing methods is

391 particularly important for conditions such as concussions, as they are characterized by many

392 symptoms which may only lead to subtle changes that are not detectable with imprecise tests.

\section{Conclusion}

394 We found that only 2 of 9 BVTs had good one-week test-retest reliability that could detect small

395 to moderate changes in visual function, and an additional 5 BVTs that might be able to detect

396 moderate change in visual function. The remaining two BVTs and saccades may still be useful if

397 changes in visual function are expected to be larger than the noise of the measure. 
medRxiv preprint doi: https://doi.org/10.1101/19011619; this version posted November 12, 2019. The copyright holder for this preprint (which was not certified by peer review) is the author/funder, who has granted medRxiv a license to display the preprint in perpetuity.

It is made available under a CC-BY-NC-ND 4.0 International license .

Running title: Concussion

\section{Acknowledgements}

400 We would like to thank Isabel Pereira for her help throughout the course of this work. We would

401 also like to thank David Tinjust, the clinician who conducted these tests in our participant

402 population and who provided partial funding for this study. This study was funded through

403 programs designed to foster collaboration between academics and industry. The government

404 sources are the MITACS program, and the MEDTEQ program. The industry partners were

405 Apexk Inc, Varitron Technologies Inc and I'Institut National du Sport du Quebec.

\section{Appendix}

407 The Appendix expands on the concise description of the nine binocular vision tests and test of

408 saccades provided in the manuscript. This is especially important when comparing results

409 across different studies in evidence synthesis. 
Running title: Concussion

\section{References}

$412 \quad 1 . \quad$ SCAT3. Br J Sports Med. 2013;47(5):259.

413 2. Adams WE, Leske DA, Hatt SR, Holmes JM. Defining real change in measures of stereoacuity.

$414 \quad$ Ophthalmology. 2009;116(2):281-285.

$415 \quad 3 . \quad$ Alpern M. The after effect of lateral duction testing on subsequent phoria measurements. Am J $416 \quad$ Optom Arch Am Acad Optom. 1946;23(10):442-447.

417 4. Alvarez TL, Kim EH, Vicci VR, Dhar SK, Biswal BB, Barrett AM. Concurrent vision dysfunctions in 418 convergence insufficiency with traumatic brain injury. Optometry and vision science : official $419 \quad$ publication of the American Academy of Optometry. 2012;89(12):1740-1751.

420 5. Antona B, Barrio A, Barra F, Gonzalez E, Sanchez I. Repeatability and agreement in the measurement of horizontal fusional vergences. Ophthalmic \& physiological optics : the journal of

6. Biousse V, Skibell B, Watts R, Loupe D, Drews-Botsch C, Newman N. Ophthalmologic features of Parkinson's disease. Neurology. 2004;62:177-180.

425 7. Bishop A. Convergence and convergent fusional reserves - investigation and treatment. In: Doshi S, Evans BJW, eds. Binocular Vision and Orthoptics: Investigation and Management. Oxford: Butterworth-Heineman; 2001:30-62.

428 8. Bland JM, Altman DG. Statistical methods for assessing agreement between two methods of clinical measurement. Lancet. 1986;1(8476):307-310.

430 9. Bredemeyer H, Bullock K. Methods of examination. Orthoptics: Theory and Practice. St. Louis: The C.V. Mosby Company; 1968:130-152.

432 10. Brozek J, Simonson E, Bushard W, Peterson J. Effects of practice and the consistency of repeated measurements of accommodation and vergence. Am J Ophthalmol. 1948;31(2):191-198. 
medRxiv preprint doi: https://doi.org/10.1101/19011619; this version posted November 12, 2019. The copyright holder for this preprint (which was not certified by peer review) is the author/funder, who has granted medRxiv a license to display the preprint in perpetuity.

It is made available under a CC-BY-NC-ND 4.0 International license .

Running title: Concussion

434 11. Capo-Aponte JE, Urosevich T, Temme L, Tarbett A, Sanghera N. Visual dysfunctions and symptoms during the subacute stage of blast-induced mild traumatic brain injury. Mil Med.

12. Ciuffreda KJ, Kapoor N, Rutner D, Suchoff IB, Han ME, Craig S. Occurrence of oculomotor dysfunctions in acquired brain injury: a retrospective analysis. Optometry (St Louis, Mo).

13. Convergence Insufficiency Treatment Trial Study G. The convergence insufficiency treatment

14. de Jongh E, Leach C, Tjon-Fo-Sang MJ, Bjerre A. Inter-examiner variability and agreement of the alternate prism cover test (APCT) measurements of strabismus performed by 4 examiners. Strabismus. 2014;22(4):158-166.

16. Ettinger U, Kumari V, Crawford T, Davis R, Sharma T, Corr P. Reliability of smooth pursuit, fixation, and saccadic eye movements. Psychophysiology. 2003;40:60-628.

17. Fawcett SL, Birch EE. Interobserver test-retest reliability of the Randot preschool stereoacuity test. Journal of AAPOS : the official publication of the American Association for Pediatric Ophthalmology and Strabismus. 2000;4(6):354-358.

18. Giffard P, Daly L, Treleaven J. Influence of neck torsion on near point convergence in subjects

455 19. Goss DA, Becker E. Comparison of near fusional vergence ranges with rotary prisms and with prism bars. Optometry (St Louis, Mo). 2011;82(2):104-107. 
medRxiv preprint doi: https://doi.org/10.1101/19011619; this version posted November 12, 2019. The copyright holder for this preprint (which was not certified by peer review) is the author/funder, who has granted medRxiv a license to display the preprint in perpetuity.

It is made available under a CC-BY-NC-ND 4.0 International license .

Running title: Concussion

20. Granet D, Gomi C, Miller-Scholte A. The relationship between convergence insufficiency and ADHD. Strabismus. 2005;13:163-168.

21. Grosvenor T. Primary Care Optometry: Anomalies of Refraction and Binocular Vision. Boston: Butterworth-Heinemann; 1996.

22. Hayes GJ, Cohen BE, Rouse MW, De Land PN. Normative values for the nearpoint of convergence of elementary schoolchildren. Optometry and vision science : official publication of the American Academy of Optometry. 1998;75(7):506-512.

23. Hurtt J, Rasicovici A, Windsor C. Diagnosis and diagnostic tests. Comprehensive Review of Orthoptics and Ocular Motility: Theory, Therapy, and Surgery/. 2nd ed. Saint Louis: The C.V.

24. Kaas JH. The evolution of the complex sensory and motor systems of the human brain. Brain Res Bull. 2008;75(2-4):384-390.

25. Kontos AP, Elbin RJ, Schatz P, et al. A revised factor structure for the post-concussion symptom scale: baseline and postconcussion factors. Am J Sports Med. 2012;40(10):2375-2384.

26. Koo TK, Li MY. A guideline of selecting and reporting intraclass correlation coefficients for reliability research. J Chiropr Med. 2016;15(2):155-163.

27. Maples WC, Hoenes R. Near point of convergence norms measured in elementary school children. Optom Vis Sci. 2007;84(3):224-228.

28. Moganeswari D, Thomas J, Srinivasan K, Jacob GP. Test re-test reliability and validity of different 2015;9(11):NC01-05. 
medRxiv preprint doi: https://doi.org/10.1101/19011619; this version posted November 12, 2019. The copyright holder for this preprint (which was not certified by peer review) is the author/funder, who has granted medRxiv a license to display the preprint in perpetuity.

It is made available under a CC-BY-NC-ND 4.0 International license .

Running title: Concussion

30. Paut O, Vercher J-L, Blin O, et al. Evaluation of saccadic eye movements as an objective test of recovery from anaesthesia. Acta Anaesthesiol Scand. 1995;39:1117-1124.

31. Pearce KL, Sufrinko A, Lau BC, Henry L, Collins MW, Kontos AP. Near point of convergence after

32. Pediatric Eye Disease Investigator Group. Interobserver reliability of the prism and alternate cover test in children with esotropia. Arch Ophthalmol. 2009;127(1):59-65.

33. Penisten $\mathrm{D}$, Hofstetter $\mathrm{H}$. Reliability of rotary prism fusional vergences ranges. Optometry (St Louis, Mo). 2001;72:117-122.

34. R Core Team. R: a language and environment for statistical computing. . Vienna, Austria: R Foundation for Statistical Computing; 2015.

35. Rosenfield M, Ciuffreda KJ, Ong E, Super S. Vergence adaptation and the order of clinical vergence range testing. Optometry and vision science : official publication of the American Academy of Optometry. 1995;72(4):219-223.

36. Rouse M, Borsting E, Deland P, The Convergence Insufficiency and Reading Study (CIRS) Group.

37. Rowe F. Investigative procedures. Clinical Orthoptics. 3rd ed. Chichester, West Sussex: Wiley-

38. Saville DJ. Multiple comparison procedures: The practical solution. Am Stat. 1990;44(2):174-180. 
medRxiv preprint doi: https://doi.org/10.1101/19011619; this version posted November 12, 2019. The copyright holder for this preprint (which was not certified by peer review) is the author/funder, who has granted medRxiv a license to display the preprint in perpetuity.

It is made available under a CC-BY-NC-ND 4.0 International license .

Running title: Concussion

40. Scheiman M, Mitchell GL, Cotter S, et al. A randomized clinical trial of treatments for convergence insufficiency in children. Arch Ophthalmol. 2005;123:14-24.

41. Scheiman M, Wick B. Diagnostic testing. Clinical management of binocular vision: Heterophoric accommodative, and eye movement disorders. Maryland, USA: Wolters Kluwer/Lippincott

42. Shrout PE, Fleiss JL. Intraclass correlations: uses in assessing rater reliability. Psychological bulletin. $1979 ; 86(2): 420-428$.

512 43. Stereo Optical Co. Randot Stereotests. In: Stereo Optical Co., ed; 1995.

513 44. Suchoff IB, Kapoor N, Ciuffreda KJ. An overview of acquired brain injury and optometric

45. Ventura RE, Balcer L, Galetta SL. The Concussion Toolbox: The Role of Vision in the Assessment of Concussion. Semin Neurol. 2015;35(5):599-606.

46. Vision in Preschoolers (VIP) Study Group. Random Dot E Stereotest: Testability and reliability in for Pediatric Ophthalmology and Strabismus. 2006;10(6):507-514.

47. von Noorden G. Examination of the patient-II: motor signs in heterophoria and heterotropia.

48. Wang J, Hatt SR, O'Connor AR, et al. Final version of the distance Randot Stereotest: normative data, reliability, and validity. Journal of AAPOS : the official publication of the American

526 49. Watson PF, Petrie A. Method agreement analysis: a review of correct methodology. Theriogenology. 2010;73(9):1167-1179.

528 50. Wickham H. ggplot2: elegant graphics for data analysis. New York: Springer-Verlag; 2009. 
medRxiv preprint doi: https://doi.org/10.1101/19011619; this version posted November 12, 2019. The copyright holder for this preprint (which was not certified by peer review) is the author/funder, who has granted medRxiv a license to display the preprint in perpetuity. It is made available under a CC-BY-NC-ND 4.0 International license .

Running title: Concussion

529 51. Yengo-Kahn A, Hale A, Zalneraitis B, Zuckerman SL, Sills A, Soloman G. The sports concussion assessment tool: a systematic review. Neurosurg Focus. 2016;40(4):E6. 